\title{
CLUSTER ANALYSIS AMONG NINE COTTON GENOTYPES
}

\begin{tabular}{|c|c|c|c|c|}
\hline $\begin{array}{l}\text { B. J. Mahmood } \\
\text { Assist. Prof. }\end{array}$ & $\begin{array}{l}\text { L. Q. Ahmed } \\
\text { Lecturer }\end{array}$ & $\begin{array}{l}\text { K. Kamal } \\
\text { Assist. Lecturer }\end{array}$ & $\begin{array}{l}\text { A. Hamedi } \\
\text { Researcher }\end{array}$ & $\begin{array}{l}\text { A. Ahmad } \\
\text { Researcher }\end{array}$ \\
\hline
\end{tabular}

Bahar.mahmmod@su.edu.krd

\section{ABSTRACT}

The field trial was conducted at Qwshtapa district, Grdmala village, which is $30 \mathrm{~km}$ far from center of Erbil city to compare between nine genotypes of cotton (Gossipum hirsutum L) during the growing season 2016, the genotypes were (Coker 310, Lachata 'Iraqi genotypes' Cafko, Dunn 1047, Montana, Stone Ville ' USA genotypes ', Bakhtegon, Khdorda , Vanamin Iranian genotypes ) using randomized complete block design (RCBD)with three replicates. any fertilizers were not added to the field during the research and Irrigation was done using Statistical analysis of the traits shown significant differences among genotypes, Coker 310 obtained the highest value for number of fruiting brunches, number of Bolls plant ${ }^{-1}$ 'Boll weight (g), seed yield plant ${ }^{-1}$, ginning\% and oil\% with values of $(8.93,29.27,4.23,, 77.67$, 39.87 and 28.33 ) respectively. Lashata genotype recorded highest value of protein and linoleic acid \% which were (34.82 and 63.68) \% respectively. Depending on growth stage, agronomic characteristics and their quality the genotypes were discerning to three main clusters, the first one included (Lachata and Stone Ville) genotypes, while the second clusters indicated only Cafko genotype and the third cluster included (Coker 310, Dunn 1047and, Montana, Bakhtegon, Khdorda and Vanamin) genotypes.

Keywords: Cotton genotypes, yield, seeds quality, Cluster analysis.

محمود و آخرون

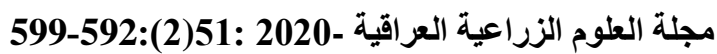
التحليل العنقودي بين تسعة تراكيب وراثية من القطن

\begin{tabular}{|c|c|c|c|c|}
\hline ئازاد احمد & ايدين حميدى & كزال كمال محمد & لينا قادر احمد & بهار جلال محمود \\
\hline باحث & باحث & ملرس مساعد & مدرس & استاذ مساعد \\
\hline
\end{tabular}

المستخلص أجريت تجربة حقلية في مزرعة قوشتبه، قرية كردملا على بعد 30 كم من وسط محافظة أربيل للمقارنة بين تسعة انماط وراثية من القطن (Gossipum hirsutum L) خلا ل موسم النمو 2016، الانماط المستخدمة فى البحث كانت الاصناف العراقية (كوكر 310 ولاشاتا)، الاصناف الامريكية ( كافكو، دون 1047 ،مونتانا و ستون فالى) اما الانماط الوراثية الايرانية كانت

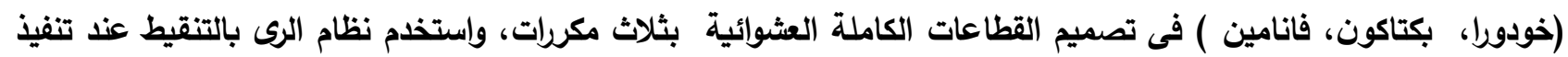

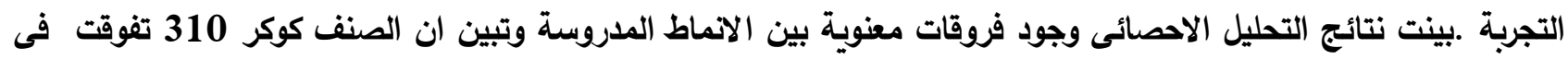

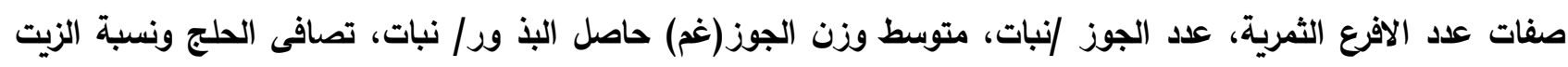

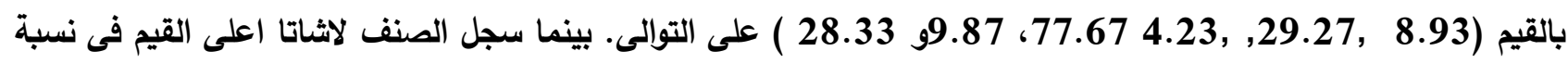
البروتين ونسبة حامض اللينوليك بالقيم 34.82(و

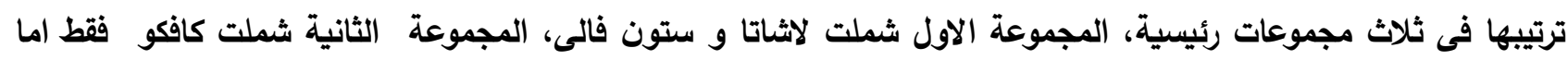

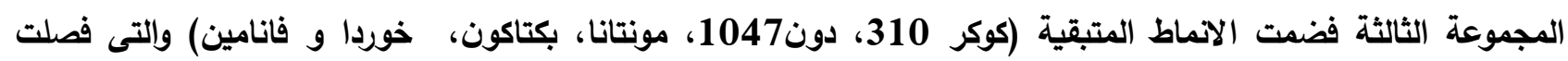

بحسب صفات النمو، الحاصل و النوعية. الكلمات المفتاحية: الانماط الوراثية للقطن، الحاصل، النوعية، التحليل العنقودى. 


\section{INTRODUCTION}

Cotton (Gossypium hirsutum L.) regards as a white gold, which is occupying a prominent position in oil and textile industry, it serves as a backbone of the countries that made it as cash crops, and is a significant source of foreign exchange earnings (1). Cotton is the second most important oilseed crop in the world (2). The oil of cotton seeds regards as the preferred vegetable oil, that produces the most flavorful potato chips on the market. The hydrogenate is not necessary for increasing its oil stability (3). The growth and seed cotton production per unit area is affected by the following factors: Genotypes, sowing time, soil status, and environmental conditions (4). The yield of cotton was affected significantly by genotypes and sowing dates (5). On the other hand (6) referred that genotypes have a significant role in production of cotton crop, there were highly significant differences among genotypes for all qualitative and quantitative traits. (7) reported from their study on three genotypes of cotton that there were e significant differences for number of bolls and its components (seed and lint). From a comparisons study among six genotypes (8) stated that the genotype Lachata was superior in seed yield, boll weight and ginning out turn with the values of $\left(4.20 \mathrm{Mg} \mathrm{ha}^{-1}, 5.25 \mathrm{~g}\right.$ and $3.38 \%$ ) respectively. The degree of variation in growth and dry matter partitioning was explored among nine cotton genotypes of diverse growth habit and how these may affect crop maturity. Because cotton is an indeterminate species, the timing of crop maturity is largely determined by the capacity of the plant to continue the production of new vegetative organs and the associated fruiting sites (9). The results obtained from the study on four cultivars ( CIM-499,CIM-473 CIM496 and CIM-506 ) of upland cotton that there were significant differences between the cultivars in seed yield the highest value was (2.45), while the lowest value was $(1.20 \mathrm{~kg}$ $\left.\mathrm{ha}^{-1}\right)(10)$.Since there are little studies about comparison among different American , Iranian and local genotypes ,for this reason this study was conducted to focus on the effect of different genotypes on yield, yield components and oil quality of nine cotton genotypes.

\section{MATERIALS AND METHODS}

The field experiment was carried out during summer growing season 2016 at Qwshtapa district, the village of Grdmala $30 \mathrm{~km}$ far from center of Erbil city, with GPS reading of $360^{\circ}$ ON and 44001 E,0411359,03997002 UTM 44 $03^{0}, 413.8 \mathrm{~m}$ above sea level $\mathrm{E}$ using randomized complete block design (RCBD) with three replicates. Nine cotton genotypes were used which two Iraqi genotypes (Coker 310 and Lachata), four USA genotypes (Cafko, Dunn 1047, Montana and Stone Ville) and three Iranian genotypes ( Bakhtegon, Khdorda and, Vanamin ) The area of each plot was $6 \mathrm{~m}^{2}\left(3^{*} 2 \mathrm{~m}\right)$, the distances between rows were $70 \mathrm{~cm}$ and plant to plant was $25 \mathrm{~cm}$ so each plot contains 32 plants. On $30^{\text {th }}$ April, the cotton seeds were sown uniformly using seed rate of $25 \mathrm{~kg} \mathrm{ha}^{-1}$. The soil properties were recorded in table(1).

Table 1. Some physic-chemical properties of the studied soil.*

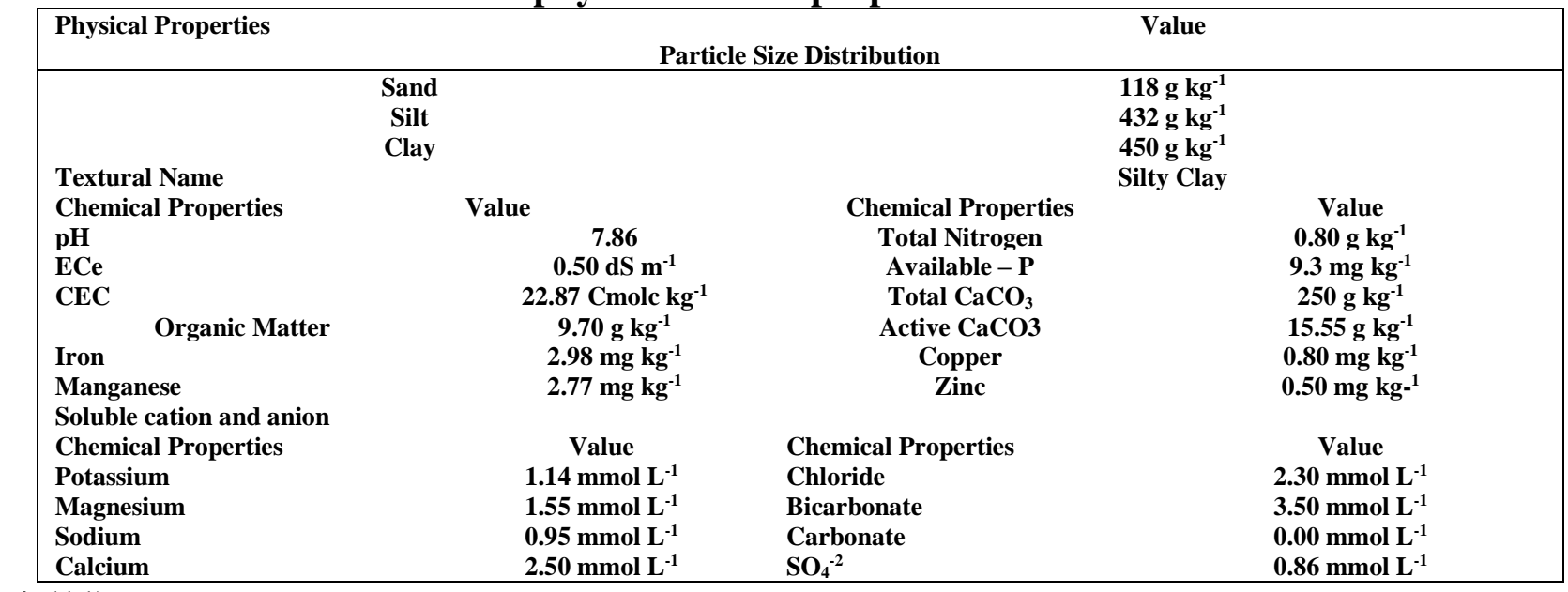

* (11) 
The thinning of plants was on $16^{\text {th }}$ June; Irrigation was done using drip irrigation methods (DIM), which is one of the technical measures to increase water use efficiency. Under this method, water is delivered directly to the root zone of the crops using pipe networks and emitters. This method is entirely different from the conventional (11), the amount of water applied was $1 \mathrm{~L} \cdot \mathrm{hr}^{-1}$, all other agricultural practices were done whenever necessary. Randomly 10 plants were taken from each treatment at the mature stage (opening $60 \%$ of bolls) for measuring and collecting different parameters, in depending on Fattah (9). Some traits were recorded including plant height $(\mathrm{cm})$, number of bolls per plant, boll weight $(\mathrm{g})$, weight of 100 seeds $(\mathrm{g})$ and yield of cotton seeds $\left(\mathrm{kg} \mathrm{ha}^{-1}\right)$, The cotton bolls were harvested according to genotypes that were cultivated separately, finally the cotton seed calculated in unit $\mathrm{kg}$ per hectare. The 100 seeds were taken from each treatment and measured in gram).

\section{Ginning out turn (GOT)}

Before the ginning, seed cotton samples were air dried. Dusts and inert matter were removed from samples and then weighed and ginned separately manually. The lint obtained from each sample was weighed and its percentage was calculated by applying the following formula.

\section{Ginning out turn (GOT) = $\frac{\text { Weight of lint }}{\text { weight of seed }+ \text { lint }} \times 100$

The oil was determined by Soxhlet extraction apparatus using hexane according to the methods described by Mahmood et al. (13). The Total Nitrogen was determined using the Kjeldahl method then the protein percentage was determined as follow:

Protein $\%=\mathrm{N} \% \times$ constant value which equal to 6.25 Statistical analysis was done using SPSS program version 25 for comparing between means using Duncan's multiple range test at probability $(\mathrm{p} \leq 0.95)$ (14). Cluster analysis was conducted between studied genotypes using XLSTAT-Premium Program to obtain homogenous groups by agglomerative hierarchical clustering (AHC) and principal component analysis (PCA), to show the similarity and dissimilarity between genotypes (15).

\section{RESULTS AND DISCUSSION}

This study showed significant results indicating varying genetic diversity of the genotypes for the studied characters such as, plant height, number of fruiting brunch, number of bolls per plant, boll weight and seed yield per plant and boll yield ha ${ }^{-1}$. Table 2 shows significant effect between genotypes on plant height, the highest value $(125.40 \mathrm{~cm})$ was recorded for Lachata, While the lowest value $(103.13 \mathrm{~cm})$ recorded for Bakhtegon genotype this results was in agreement with those recorded by Saeed et al. (16). The highest values has for number of fruiting branch, number of bolls Plant ${ }^{-1}$, bolls weight (g) and seed yield plant ${ }^{-1}$ were recorded from Coker 310 with the values of( 8.93,29.27,4.23 and 77.67)respectively, while the lowest values of them (7.20,19.00,3.58and 60.23) were obtained for Khdorda genotypes respectively, these results explain that the genotype is the main factor affected on the above traits (17), or it means that genotypes are differing in their adaptation to Erbil environments. The same Table, shows the significant variation in biological yield among the genotypes, Lachata was recorded the highest (3.58) $\mathrm{Mg} \mathrm{ha}^{-1}$ biological yield, while Vanamin genotypes recorded the lowest (2.13) $M g$ ha $^{-1}$. This could be due the difference in yield genetic potentiality of the studied genotypes (18). The dynamics of dry matter production and reproductive demand may also have a significant impact on the yield of different genotypes (9). 
Table 2. Effect of genotypes on some growth and yield characteristics

\begin{tabular}{|c|c|c|c|c|c|c|c|c|}
\hline 苋 & 壳 & 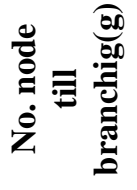 & Z & 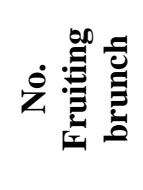 & $\stackrel{\dot{0} \bar{\varnothing}}{\bar{Z}}$ & 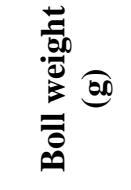 & 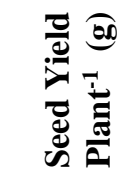 & 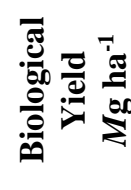 \\
\hline Coker 310 & 105.07bc & $4.87 a$ & 3.33a & $8.93 \mathrm{a}$ & 29.27a & $4.23 \mathrm{a}$ & $77.67 a$ & 3.39a \\
\hline Lachata & $125.40 \mathrm{a}$ & 4.33a & $3.87 \mathrm{a}$ & $8.13 \mathrm{ab}$ & 22.80ab & 3.66ab & 68.91ab & $3.58 \mathrm{a}$ \\
\hline Cafko & 118.53ab & 4.53a & $3.67 a$ & $8.40 \mathrm{ab}$ & 20.27ab & $3.62 \mathrm{~b}$ & $63.58 b c$ & $3.16 \mathrm{a}$ \\
\hline Dunn 1047 & 107.80bc & $4.20 \mathrm{a}$ & 4.53a & 8.8 ab & 21.53ab & $3.32 \mathrm{~b}$ & 67.91ab & $2.92 \mathrm{ab}$ \\
\hline Montana & $103.15 c$ & $5.33 \mathrm{a}$ & $4.27 a$ & $7.33 \mathrm{ab}$ & $17.40 b$ & $3.45 \mathrm{~b}$ & 61.88bc & $2.87 \mathrm{ab}$ \\
\hline Stone ville & 115.00abc & $4.67 a$ & $4.27 \mathrm{a}$ & $8.60 \mathrm{ab}$ & $19.40 b$ & $3.72 \mathrm{ab}$ & $64.55 \mathrm{bc}$ & $2.81 \mathrm{ab}$ \\
\hline Bakhtegon & $103.13 c$ & $5.27 \mathrm{a}$ & $4.2 \mathrm{a}$ & $7.33 \mathrm{ab}$ & $16.47 b$ & $3.84 \mathrm{ab}$ & 74.03ab & $2.68 \mathrm{ab}$ \\
\hline Khdorda & $105.47 b c$ & $5.40 \mathrm{a}$ & $3.4 \mathrm{a}$ & $7.20 \quad \mathrm{~b}$ & $19.00 b$ & $3.58 \mathrm{~b}$ & $60.23 c$ & $3.02 \mathrm{ab}$ \\
\hline Vanamin & $110.80 b c$ & $4.60 \mathrm{a}$ & $4.28 \mathrm{a}$ & 7.60ab & $17.73 b$ & $3.56 \mathrm{~b}$ & $50.76 \mathrm{a}$ & $2.13 \mathrm{~b}$ \\
\hline
\end{tabular}

Table 3 Refers to the significant differences The highest seed $\%$ and net ginning out $\%$ among the studied genotypes, Bakhtegon recorded the highest value for seed index and fiber plant ${ }^{-1}$ with the values of (6.40 and 8.65) respectively. While their lowest values $(5.13$ and 6.46) were obtained from Cafko and Montana genotypes respectively, since the seed index was mostly affected by genotypes because it depends on velocity of seed growth which considered genetic characters and to be the main goal from cotton production (16). (64.80 and 39.87) \% were recorded from Lachata and Coker 310 genotypes respectively, while their lowest values (60.13\% and 35.40) Lachata and Cafko genotypes respectively. These results were in agreement with Others (19), they found that differences in ginning may be due to differentiation between genotypes and total cotton lint yield which reflect positively on this characteristics as mentioned by (16).

Table 3. The comparison between genotypes on some field characteristics

\begin{tabular}{|c|c|c|c|c|c|c|c|c|}
\hline \multirow{2}{*}{$\begin{array}{l}\text { Genotypes } \\
\text { Coker } 310\end{array}$} & \multicolumn{2}{|c|}{ Seed index } & \multicolumn{2}{|c|}{ Seed \% } & \multicolumn{2}{|c|}{ Ginning } & \multicolumn{2}{|c|}{ Fiber/plant } \\
\hline & 5.30 & b & 63.91 & $\mathbf{a b}$ & 39.87 & $\mathbf{a}$ & 6.64 & b \\
\hline Lachata & 5.52 & $\mathbf{a b}$ & 64.60 & $\mathbf{a}$ & 35.40 & b & 6.48 & b \\
\hline Cafko & 5.13 & $\mathbf{b}$ & 60.13 & $\mathbf{b}$ & 36.09 & $\mathbf{a b}$ & 6.55 & b \\
\hline Dunn 1047 & 5.63 & $\mathbf{a b}$ & 64.01 & $\mathbf{a b}$ & 35.99 & $\mathbf{a b}$ & 6.89 & b \\
\hline Montana & 5.42 & $\mathbf{a b}$ & 62.55 & $\mathbf{a b}$ & 37.45 & $\mathbf{a b}$ & 6.46 & b \\
\hline Stone ville & 5.58 & $\mathbf{a b}$ & 61.99 & $\mathbf{a b}$ & 38.01 & $\mathbf{a b}$ & 7.02 & b \\
\hline Bakhtegon & 6.40 & $\mathbf{a}$ & 60.91 & $\mathbf{a b}$ & 39.09 & $\mathbf{a b}$ & 8.65 & $\mathbf{a}$ \\
\hline Khdorda & 5.56 & ab & 62.65 & $\mathbf{a b}$ & 37.35 & $\mathbf{a b}$ & 6.64 & b \\
\hline Vanamin & 5.28 & b & 62.13 & ab & 37.87 & ab & 6.74 & b \\
\hline
\end{tabular}

The results in Table 4 shows significant effect of cotton genotypes on oil \% the highest and lowest values (36.33 and $18.33 \%)$ were obtained for Coker 310 and Stone Ville genotype respectively, these differences contributed to their genetic properties. While the highest values for both protein $\%$ and linoleic acid\% (34.82 and 63.68 ) \% were obtained for Lachata genotype and the lowest values(28.47 and 26.90) \% were recorded for Vanamin and Cafko respectively. These results are in agreement with (20) they indicated that

oil $\%$ and protein $\%$ in cotton were $(18-26 \%)$ and $(32-36 \%)$ respectively. It is appear from the same Table that highest and lowest values of oleic acid were found from Stone Ville and Cafko genotype respectively. On the other hand the highest and lowest values of linolenic content were recorded from Dunn 1047 and Vanamin genotypes. 
Table 4.The comparison between genotypes on some quality characteristics

\begin{tabular}{|c|c|c|c|c|c|}
\hline Genotypes & Oil \% & Protein\% & Oleic\% & Linoleic\% & Linolenic \% \\
\hline Coker 310 & 28.33a & $29.25 d$ & $15.96 \mathrm{~g}$ & 53.34b & $0.51 c$ \\
\hline Lachata & $25.00 b$ & 34.82a & $35.94 b$ & $63.68 \mathrm{a}$ & $0.40 \mathrm{c}$ \\
\hline Cafko & 26.00ab & $31.32 \mathrm{c}$ & $15.88 \mathrm{~g}$ & $26.90 \mathrm{~h}$ & $1.46 \mathrm{~b}$ \\
\hline Dunn 1047 & 24.33bc & 33.22ab & 27.70d & 45.87d & $2.25 \mathrm{a}$ \\
\hline Montana & $20.67 d$ & 34.13a & 28.61c & 45.53d & $0.58 c$ \\
\hline Stone ville & 19.67d & $34.76 a$ & $47.56 \mathrm{a}$ & 48.30c & $1.69 \mathrm{~b}$ \\
\hline Bakhtegon & $24.67 b c$ & 33.71a & 21.79f & $33.55 \mathrm{~g}$ & $1.47 b$ \\
\hline Khdorda & 24.00bc & 31.73bc & $35.71 b$ & $36.75 f$ & $0.39 \mathrm{c}$ \\
\hline Vanamin & 22.00d & 28.47d & 24.59e & $39.94 \mathrm{e}$ & $0.33 c$ \\
\hline
\end{tabular}

Fig 1 explains the results of statistical analysis Montana, Bakhtegon, Khdorda, and Vanamin). using Dendrogram, which classified the The genotypes within the same cluster are genotypes to three main clusters, the first one similar in the studied characters. It explains included (Lachata and Stone Ville), the second that the Dunn1047 and Montana genotypes clusters included only Cafko genotype and the are much more similar than Vanamin in the third cluster included the remain genotypes same clusters.

which were (Coker 310, Dunn 1047and,

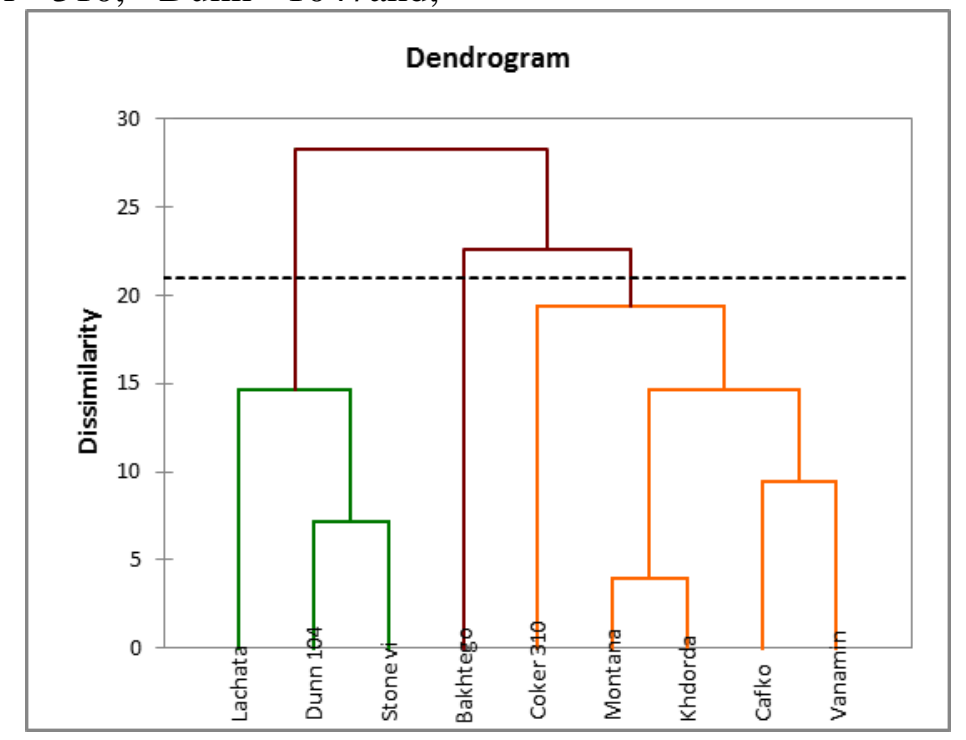

Fig 1. Dendrogram obtained from a cluster analysis of the genotypes

Table 5 shows the proximity matrix of this research, which refers to similarity and dissimilarity, the highest value (43.32) refers to higher dis-similarity. Relationship between the two Genotypes Lachata and Cafko, the same dis-similarity were obtained between
Lachata and Bakhtegon (41.68) it means there are highest differences between them while the value of 8.32 refers to the similar relation between Dunn 1047and, Montana as mentioned

Table 5. The proximity matrix (Euclidean distance)

\begin{tabular}{|ccccccccc|}
\hline & Coker 310 & Lachata & Cafko & $\begin{array}{c}\text { Dunn } \\
1047\end{array}$ & Montana & Stone Ville & Bakhtegon & Khdorda \\
\hline $\begin{array}{c}\text { Coker 310 } \\
\text { Lachata }\end{array}$ & $\mathbf{3 1 . 9 8 8}$ & & & & & & & \\
Cafko & $\mathbf{3 2 . 3 8 2}$ & $\underline{43.316}$ & & & & & & \\
Dunn 1047 & $\mathbf{2 0 . 4 6 5}$ & $\mathbf{2 7 . 8 3 7}$ & $\mathbf{2 5 . 5 9 3}$ & & & & & \\
Montana & $\mathbf{2 3 . 6 9 1}$ & $\mathbf{3 2 . 3 8 8}$ & $\mathbf{2 8 . 3 5 8}$ & $\underline{\mathbf{8 . 3 2 4}}$ & & & & \\
Stone ville & $\mathbf{3 8 . 8 7 7}$ & $\mathbf{2 6 . 5 2 6}$ & $\mathbf{3 9 . 7 6 3}$ & $\mathbf{2 2 . 3 6 5}$ & $\mathbf{2 3 . 0 5 3}$ & & & \\
Bakhtegon & $\mathbf{2 5 . 9 4 3}$ & $\underline{41.677}$ & $\mathbf{2 2 . 9 5 4}$ & $\mathbf{1 8 . 7 0 1}$ & $\mathbf{1 9 . 7 1 5}$ & $\mathbf{3 5 . 4 1 9}$ & & \\
Khdorda & $\mathbf{2 8 . 6 4 5}$ & $\mathbf{3 4 . 4 3 4}$ & $\mathbf{2 6 . 1 9 9}$ & $\mathbf{1 3 . 2 9 7}$ & $\mathbf{1 3 . 3 2 1}$ & $\mathbf{2 1 . 1 1 1}$ & $\mathbf{1 7 . 7 5 1}$ & \\
Vanamin & $\mathbf{2 3 . 2 6 8}$ & $\mathbf{3 2 . 9 1 4}$ & $\mathbf{1 8 . 5 1 2}$ & $\mathbf{1 0 . 8 2 5}$ & $\mathbf{1 2 . 1 3 8}$ & $\mathbf{2 6 . 2 7 4}$ & $\mathbf{1 8 . 2 9 6}$ & 14.299 \\
\hline
\end{tabular}

Fig 2 Shows some observations on the studied genotypes it's clear that at the right side the closest distance mean more similarity in the same cluster there are different manner between the genotypes stone Ville and Dunn104 was in the positive side while Cafko and Lachata was negative this explanation is the same for the second cluster. 


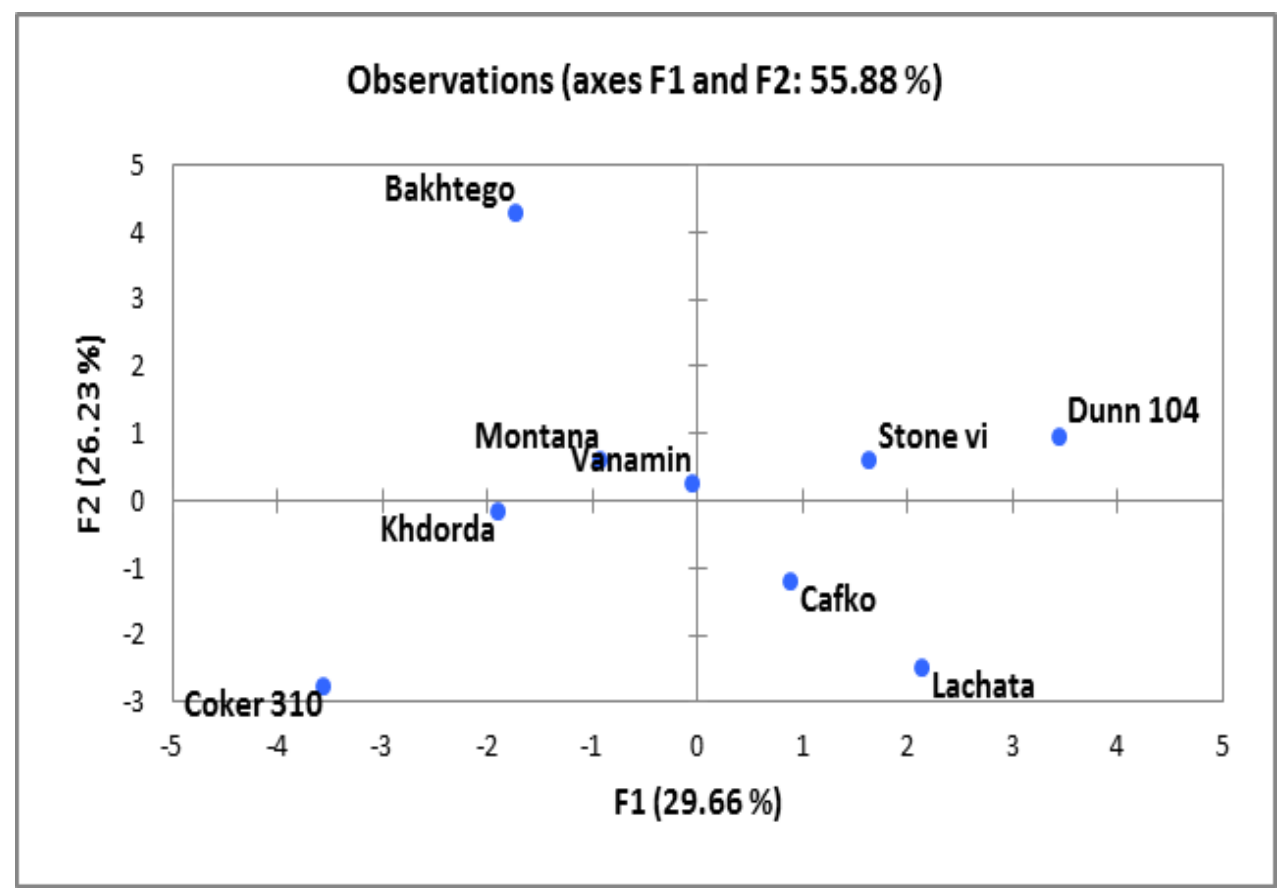

Fig 2. Cluster analysis of the characteristics of the genotypes

There is a very high correlation between seed yield and the number of the ball per plant, plant height, seed \% and linoleic acid as mentioned in Fig 3. Clustering variables can be a useful way to discover which traits or groups of traits tend to similar or vary together in a population.

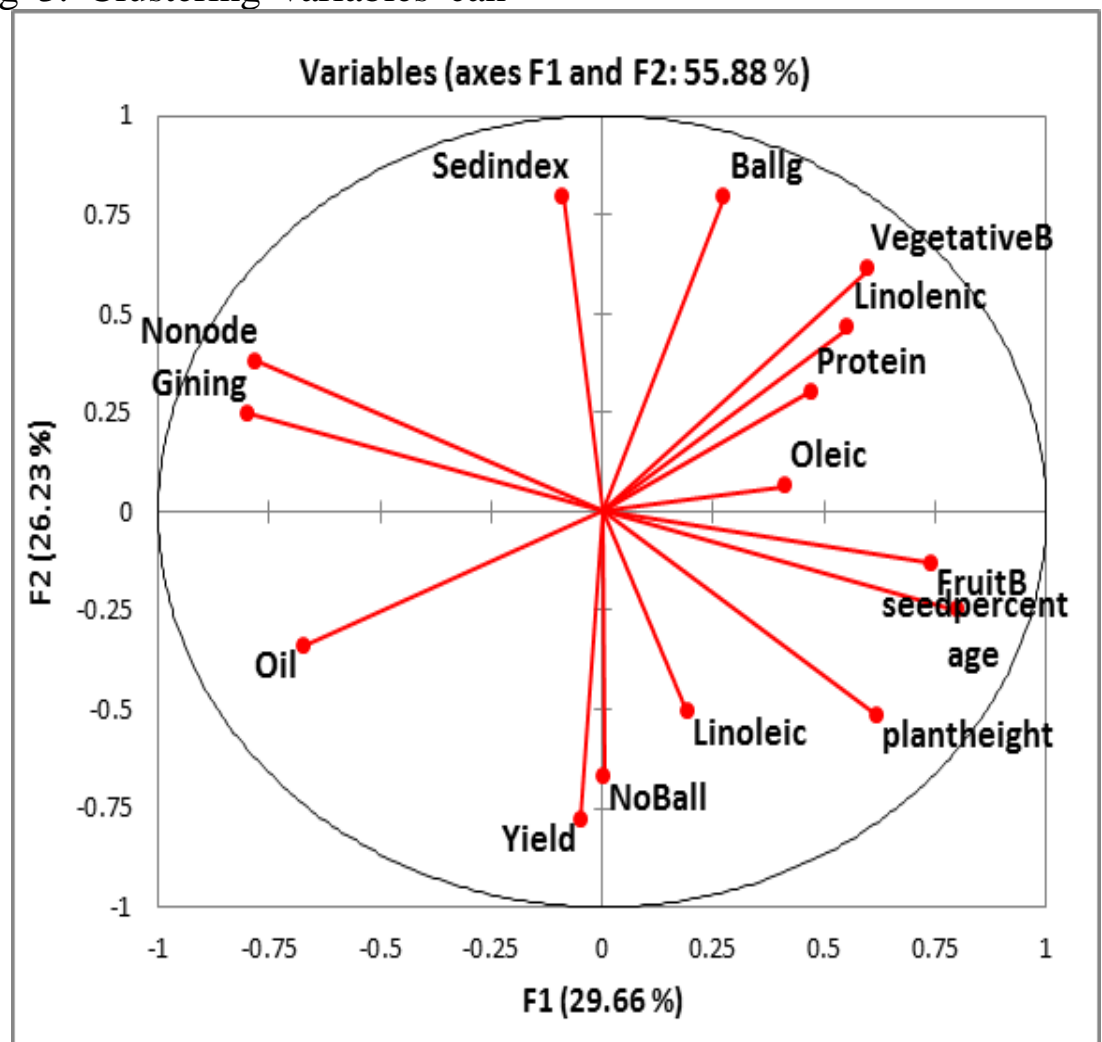

Fig 3. Cluster analysis between variables in the comparison study

In Figure 4 the genotypes and variables are merged and give a different explanation. The variables close to the center there will not be significant differences between them for example in leachate and Kafko genotype is closest in yield, seed $\%$, and fruiting brunch ...etc variables. Protein seed, oleic and linoleic is more close to Dunn 1047 and Stone -Ville genotype, any of the variables are close mean there is a positive reaction between them and the other side has a negative reaction with the first one. 


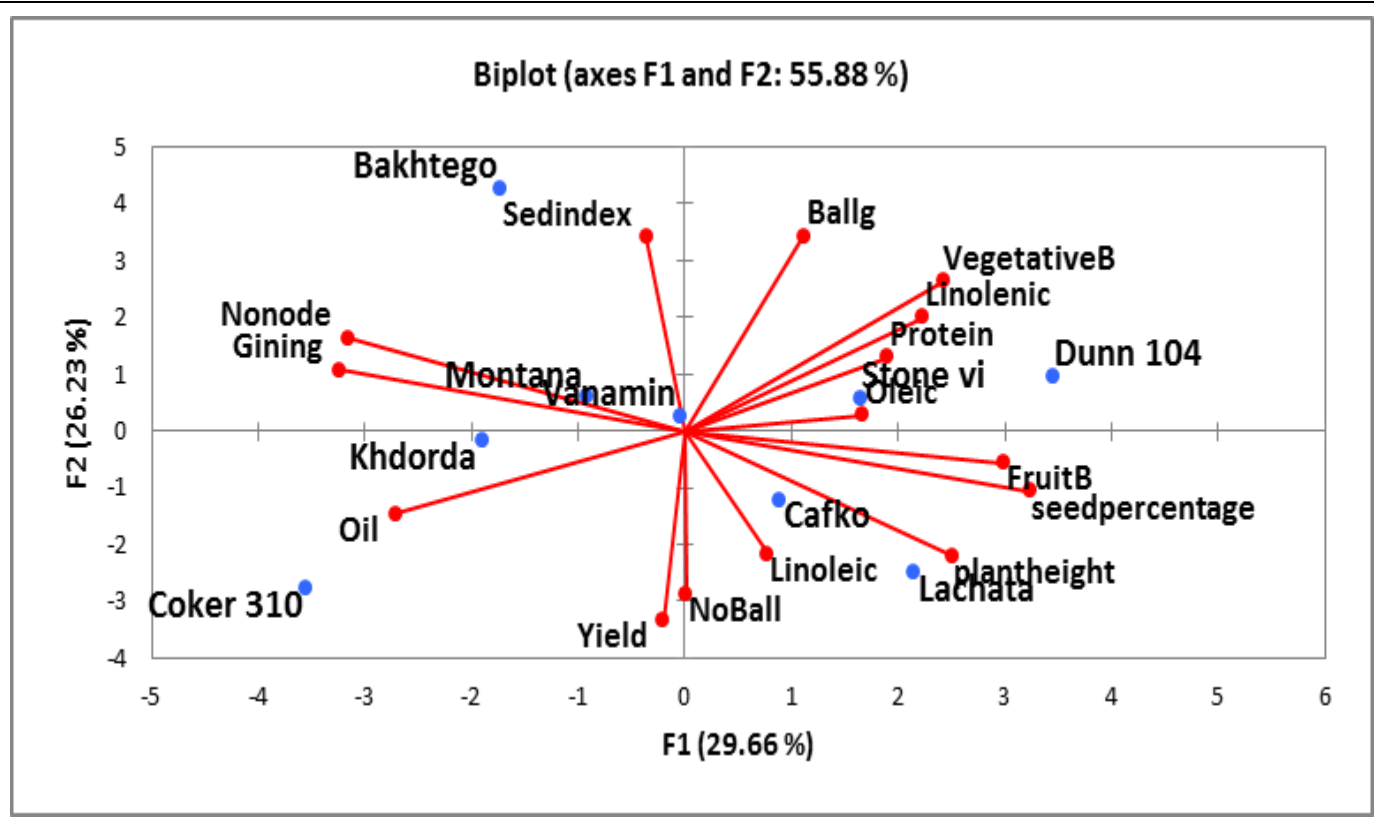

\section{Conclusion}

The studied genotypes had shown significant differences in most traits, the Lachata and Coker 310 genotypes were the most superior in most quantitative and qualitative characters comparing with other cultivars.

\section{REFERENCES}

1.A.O.A.C. 1980. Official Methods of Analysis of the Association of Official Analytical Chemists. $12^{\text {th }}$ ed.Washington, D. C 2.AL-Gubouri, A, H, A. and S, K, Ali, 2017. Genotypic by environment interaction and stability of upland cotton genotypes over diverse environments (Gosspim hirstum L.). Journal of Tikrit University for Agricultural Science. 17 (4).

3.Al-Hajooj, Y.A.M 2012. Response of some Growth Characters and Yield and Quality Properties for Genotypes of Cotton (Gossypium hirsutum L.) Under Different Planting Durations. M.Sc.Thesis, College of Agriculture, Tikrit University

4.Arshad, M: Aftab, W: M. Maqsood: Khalid Hussain: M. Aslam and M. Ibrahim 2007. Response of growth, yield, and quality of different cotton cultivars to sowing dates 5.Bange, M.P and, S.P. Milroy 2004. Growth and dry matter partitioning of diverse cotton genotypes. Field Crops Research 87, 73-87.

6.Calhoun, M,C., 2005. Variation in the Nutrient and Gossypol Content of Whole Cottonseed and Cottonseed Meal. Texas Agricultural Experiment Station Texas A\&M University System.
7.Cochran, W. G: and G. M. Cox 1957. Experimental Designs. $2^{\text {nd }}$ ed, Jon Wiley and Sons Inc, New York, USA.p 593

8.Daniel, D, R: B.S., 2003. The chemical and functional properties of cottonseed oil as a deep-fat frying medium. Graduate Faculty of Texas Tech University .ph D, thesis.

9.Fattah, K, M. 2019. Effect of organic fertilizer and intercropping on growth and yield of sweet corn and fresh bean. Van Yuzuncu Yil University.Institute of natural and applied science .ph. D. thesis.

10. https://www.xlstate.com. XLSTATE version 3.5.2014

11.Hurmzyar, K, K, M. 2014. Effect of topping treatments on seed cotton yield, its components and fiber properties for some genotypes of upland cotton (Gossypium hirsutium L.). University of Salahaddin / Erbil, MSc thesis

12.Khan, N. U; G. Hassan; K. B. Marwat; F. S. Batool; K. Makhdoom; I. Khan; I. A. Khan and W. Ahmad 2009. Genetic variability and heritability in upland cotton Pak.J. Bot.41(4):1695-1705.

13.Mahmood, B. J : S. A. Mahmood and W. O. Rasol 2011. Effect of different level of phosphor and Potash fertilizer on yield and its component of (Cotton Gossypum sp)

14.Rabadia, V. S: V. S. Thaker and Y. D. Singh 2006. inflorescence of flowering time and fruiting pattern on yield component of three cotton genotypes.Plant breeding and seed science, Department of Biosciences, 
Saurashtra, University, Rajkot, India, Vol53 17-25.

15.Raheel, Muhammad, Z. Madiha, A. Muhammad, H. Ansar, K. Sonia, Khalida, Bahuder. A. Anwar, F. A. Muhammad,: I . Zafar, N. Muhammad, 2017. Performance of different genotypes of Gossypium hirsutum under various sowing conditions on yield contributing parameters. PSM Biological Research 2(3):133-136. ISSN: 2517-9586.

16.Saeed, F., S. A. Kang, and M. Amin, 2014. Performance of genotypes at different sowing dates on yield and quality traits in Gossypium hirsutum. International Journal of Agriculture and Crop Sciences. 7 (5): 274-278.

17.Salih, R, F. 2019. Effect of Sowing Dates and Genotypes of Cotton (Gossypium hirsutum L.) on Growth and Yield Parameters. ZANCO Journal of Pure and Applied Sciences.
18.Salih, R. F. 2010. Response of Growth ,Yield and Fibers Properties for some Genotypes of Cotton (Gossypium hirsutum L) to Potassium Fertilization. M.Sc. thesis, Collage of Agriculture, University of Salahaddin (in Arabic).

19.Tabatabaei, S. A, and V. Rafieeand E. Shakeri 2012. Comparison of morphological, physiological and yield of local and improved cultivars of cotton in Yazd province.International Journal of Agriculture: Research and Review 2 (6): 755-759

20.Ul-Hassan, Mahmood: M, N, M. Z. Iqbal, I., M. Taj, I. Muhammad, and A. Saghir, 2003. Effect of different sowing dates on cotton (Gossypium hirsutum L.) cultivars. Asian Journal of Plant Science,2 (6): 461-463 ISSN 1682-3974. 